\title{
Natural feeding of the temperate asymbiotic octocoral-gorgonian Leptogorgia sarmentosa (Cnidaria: Octocorallia)
}

\author{
Marta Ribes ${ }^{1,4, *}$, Rafel Coma ${ }^{2}$, Sergi Rossi $^{3}$ \\ ${ }^{1}$ Hawaii Institute of Marine Biology, PO Box 1346, Kaneohe, Hawaii 96744, USA \\ ${ }^{2}$ Centre d'Estudis Avançats de Blanes (CSIC), Accés Cala Sant Francesc 14, PO BOX 118, 17300 Blanes, \\ Girona, Spain \\ ${ }^{3}$ Institut de Ciències del Mar (CSIC), Passeig Marítim 37-49, 08003 Barcelona, Spain \\ ${ }^{4}$ Present address: Institut de Ciències del Mar (CSIC), Passeig Marítim 37-49, 08003 Barcelona, Spain
}

\begin{abstract}
Octocorals are common components of sublittoral benthic communities in temperate, tropical and polar areas. However, their natural diets and feeding rates are poorly known. In this study, we examined natural feeding and respiration of the ubiquitous temperate species Leptogorgia sarmentosa (Cnidaria: Octocorallia) in the NW Mediterranean. We measured in situ grazing rate on dissolved organic carbon (DOC), detrital particulate organic carbon (POC) and live particulate carbon $<100 \mu \mathrm{m}$ (i.e. pico- and nanoplankton, dinoflagellates, diatoms and ciliates) using continuous flow incubation chambers. L. sarmentosa captured nanoeukaryotes, dinoflagellates, diatoms, ciliates, as well as detrital POC, but no significant capture of DOC, nor of prey items smaller than nanoeukaryotes (mean $3.6 \mu \mathrm{m}$ ), was observed. Feeding rate on detrital POC and live carbon $<100 \mu \mathrm{m}$ was $402 \pm$ 35 and $67 \pm 6 \mu \mathrm{g} \mathrm{C} \mathrm{g}$ ash-free dry mass $(\mathrm{AFDM})^{-1} \mathrm{~h}^{-1}$, respectively. Detrital POC and zooplanktonpreviously studied - were the 2 main food sources, while live carbon $<100 \mu \mathrm{m}$ accounted for less than $10 \%$ of the total ingested carbon. Respiration rate was $0.55 \pm 0.24 \mathrm{mg} \mathrm{O}_{2} \mathrm{~g} \mathrm{AFDM}^{-1} \mathrm{~h}^{-1}$ (mean $\pm \mathrm{SE}$ ), which is equivalent to a requirement of $155 \pm 67 \mu \mathrm{g} \mathrm{g} \mathrm{AFDM}^{-1} \mathrm{~h}^{-1}$. On the basis of estimated feeding and respiration rates, the respiratory demand can largely be met. The spectrum of food sources and the contribution of different food sources to the diet is consistent with previous feeding studies and suggests 2 general patterns in the diet of octocorals. First, octocorals feed on a wide spectrum of food sources ranging from ca. $4 \mu \mathrm{m}$ (nanoeukaryotes) to seston particles measuring several hundred microns. Second, despite the wide spectrum of food sources, microplankton and detrital POC constitute the bulk of the heterotrophic diet of octocorals. The contribution of detrital POC to the diet of octocorals suggests that there may be important seasonal variations in energy intake, which may affect the seasonal dynamics of temperate octocorals due to the marked seasonal variation in the availability of this particulate carbon source in temperate ecosystems like the Mediterranean.
\end{abstract}

KEY WORDS: Octocorals · Natural feeding · Respiration · Gorgonians · Benthic communities · Mediterranean Resale or republication not permitted without written consent of the publisher

\section{INTRODUCTION}

Food plays a determinant role in population and community ecology (Schoener 1974, Olson \& Olson 1989). In many shallow littoral ecosystems, benthic suspension feeders (BSF) are useful subjects to exam- ine the role of food in population and community ecology because they are abundant, they exhibit little or no movement and are dependent upon food sources available in the water column. Changes in water column productivity may induce changes in the community composition of BSF (Dayton \& Oliver 1977, Graff 1992), 
and several studies also indicate that BSF may significantly affect planktonic populations (Peterson \& Black 1987, Petersen \& Riisgård 1992, Gili \& Coma 1998). In some special environments, BSF can even control the dynamics of planktonic communities (Cloern 1982, Officer et al. 1982), although this grazing impact is highly influenced by hydrodynamic processes (Fréchette et al. 1989, Riisgård et al. 1996). Despite much evidence suggesting that the feeding ecology of benthic suspension feeders may be important in understanding littoral ecosystems, natural diets and feeding rates of benthic suspension feeders are still poorly known.

Octocorals are common components of sublittoral benthic communities in temperate, tropical and polar areas (e.g. True 1970, Kinzie 1973, Weinberg 1979, Starmans et al. 1999). In some habitats, octocorals are the main contributors to the biomass and structure of the community (True 1970), and they play an important ecological role by increasing the biomass and diversity of the community. Natural feeding rates have been shown to contribute to the understanding of life-history traits (Coma et al. 1998). Abundance and feeding rates of octocorals suggest that they may play a significant role in energy transfer processes in littoral ecosystems (Fabricius \& Dommisse 2000). However, because natural feeding on the entire spectrum of potential food sources has only been studied for a few species (Ribes et al. 1998, 1999a), this lack of information has become a limiting step in our understanding of the role of octocorals in the functioning of littoral ecosystems.

Natural prey capture rates of octocorals have been studied in several shallow-water symbiotic species, mainly by gut content examination. Zooplankton prey capture rate is low (usually below 0.3 prey per polyp, Lewis 1982, Fabricius et al. 1995). Gut content examination assesses zooplankton capture rate but underestimates small and soft-bodied prey because they leave no recognizable remains. Direct and indirect evidence from the use of other techniques shows that octocorals can also feed on phytoplankton and particulate organic matter (POM). In situ measurements of chlorophyll depletion indicate high feeding rates by Dendronephthya hemprichi on phytoplankton (0.008 g C g AFDM ${ }^{-1} d^{-1}$, Fabricius et al. 1998). Indirect evidence comes from a community study conducted on a coastal reef community of the Great Barrier Reef. This study showed that the benthic community, dominated by zooxanthellate octocorals, removed a significant amount of suspended particulate matter and estimated that octocorals had a biomass-specific ingestion rate of $0.01 \mathrm{~g} \mathrm{C} \mathrm{g} \mathrm{AFDM}^{-1} \mathrm{~d}^{-1}$ (Fabricius \& Dommisse 2000).

Gut content examination has shown significant capture of naturally occurring zooplankton prey only in temperate asymbiotic octocoral species (Alcyonium sidereum, Sebens \& Koehl 1984; Paramuricea clavata, Coma et al. 1994). Among P. clavata, the capture of zooplankton accounted for only half of its energetic requirements, suggesting that the role of other food sources should be explored (Coma et al. 1998). A subsequent study utilizing incubation chambers (Ribes et al. 1999a) showed that P. clavata also feeds on detrital POC, nano- and microplankton, with a total biomassspecific ingestion rate of $0.002 \mathrm{~g} \mathrm{C} \mathrm{g} \mathrm{AFDM}^{-1} \mathrm{~d}^{-1}$. This rate is lower than that estimated for the zooxanthellate octocoral community from the Great Barrier Reef (Fabricius \& Dommisse 2000).

Leptogorgia sarmentosa Linne 1758 (previously Lophogogia ceratophyta) is a ubiquitous and characteristic member of the benthic Mediterranean fauna that is usually found between 20 and $200 \mathrm{~m}$ depth (Carpine 1963, Weinberg 1976), although in some locations it occurs as shallow as 10 m (Banyuls-sur-mer, authors' pers. obs.). This asymbiotic octocoral gorgonian lives on boulders which are usually found on soft bottoms. Population structure, growth and secondary production of the species has been studied in the La Spezia Gulf (Ligurian Sea; Mistri \& Ceccherelli 1993, Mistri 1995). The main objective of this study was to examine the natural diet and feeding rate of the species on the entire spectrum of potential food sources. Zooplankton feeding has been previously studied (Rossi 2002). Respiration rate was quantified to examine the extent to which the different food sources examined can account for the energy demand of the species. The study contributes to the understanding of the role of dissolved organic carbon (DOC), detrital particles, pico-, nano-, and microplankton in the diet of octocorals. The study of a wide range of species is necessary to examine whether patterns emerge from particular studies. This study contributes to an examination of whether patterns in the diet of octocorals emerge from this and previous feeding studies.

\section{MATERIALS AND METHODS}

The population of Leptogorgia sarmentosa we studied was located at the Medes Islands Marine Reserve (NW Mediterranean Sea, $42^{\circ} 3^{\prime} \mathrm{N}, 3^{\circ} 13^{\prime} \mathrm{E}$ ) at ca. $20 \mathrm{~m}$ depth. Feeding on DOC, detrital particulate organic carbon (POC), and live carbon $<100 \mu \mathrm{m}$ (including pico- and nanoplankton, dinoflagellates, diatoms and ciliates) was quantified using continuous-flow circulation chambers placed in situ.

Feeding experiments. The 2 incubation chambers (1 with gorgonian and 1 control) were made from hemispherical pieces of ultraviolet (UV)-transparent Plexiglas, approximately 21 in volume. Colonies of the gorgonian Leptogorgia sarmentosa were selected to 
have a similar size and biomass $(0.35 \pm 0.05 \mathrm{~g}$ AFDM) to reduce size effect on the study of both feeding and respiration rates. Then, ca. 1 mo before the experiments, several L. sarmentosa colonies between 9 and $11 \mathrm{~cm}$ in height were removed from the substratum, cleaned of macroepibionts, and attached to artificial supports with PVC posts. These specimens were then returned to their natural environment, close to conspecifics, to acclimate to the conditions. This approach greatly reduced disturbance to the organism during subsequent experimental work. The chambers had inlet and outlet apertures, allowing the system to be operated in an open or closed mode (see Ribes et al. 2000 for a detailed description of the system). An electric pump at the outlet aperture forced water through the system at a speed of $0.024 \mathrm{l} \mathrm{s}^{-1}$ during the experiments. At this rate, the water velocity inside the chamber was about $1.2 \mathrm{~cm} \mathrm{~s}^{-1}$, creating a turbulent flow around the test animal. At the beginning of each experiment, 1 specimen was placed on the base of the experimental chamber with the second chamber serving as control. Specimens were allowed to expand fully. If the incubated specimen did not expand fully within a few minutes, it was eliminated from the experiment. During the acclimation period, the inlet and outlet apertures of both the experimental and control chambers were not connected, so the system was in open water circulation. When the polyps were fully expanded, replicate water samples of $500 \mathrm{ml}$ were collected from the outlets of both chambers (initial water samples) and preserved for further analysis (see below). Inlet and outlet apertures were then connected, the system was closed and water circulation was internal. In both chambers, oxygen concentration and temperature were continuously measured by use of Wissenschaftlich-Technische Werkstätten (WTW) oxygen electrodes, Model EOT 196. Preliminary experiments were conducted to determine the minimum time required to detect significant changes in food source (Ribes et al. 2000). A residence time of water inside the chambers of $4 \mathrm{~h}$ was determined. The drop in oxygen concentration within the chambers during this residence time was always less than $10 \%$. This drop in oxygen concentration did not affect respiration rate and animal behavior (Ribes et al. 2000), which is in accordance with the results observed in other species (Crisp 1984, Fabricius \& Klumpp 1995). Four hours after collecting the initial water samples, replicate water samples of $500 \mathrm{ml}$ were again collected from both chambers (final water samples). All experiments were conducted between 10:00 and 16:00 h, and the activity rhythm of the incubated colonies, as well as that of conspecifics, was monitored by direct observation at 30 min intervals during the experiment. The polyps of the incubated colony and conspecifics were expanded throughout the incubation. In the few cases when the polyps of the incubated colony contracted, the experiment was aborted. Grazing was calculated from the decrease in prey concentration in the experimental chamber relative to the control (see below). Potential prey items included: prokaryotes (heterotrophic bacteria, Synechococcus sp., and Prochlorococcus sp.), eukaryotic pico- and nanoplankton, ciliates, phytoplankton (diatoms and dinoflagellates), DOC and detrital POC. Water volume used for the analysis of DOC, POC, prokaryotes, eukaryotic pico- and nanoplankton was previously screened with a $100 \mu \mathrm{m}$ net to avoid larger plankters. Six incubation experiments, using a different colony each time, were carried out on 6 different days between May 14 and June 28, 1999.

We used flow cytometry to quantify heterotrophic bacteria, Prochlorococcus sp., Synechococcus sp., and picoeukaryotes. Water samples $(2 \mathrm{ml})$ were fixed with $1 \%$ paraformaldehyde $+0.05 \%$ glutaraldehyde (final concentration), frozen in liquid nitrogen, and stored at $-80^{\circ} \mathrm{C}$. For determination of bacterial and picoeukaryote abundance we used a B\&D FACScalibur bench machine with a laser emitting at $488 \mathrm{~nm}$. Heterotrophic bacteria were stained with Syto 13 (Molecular Probes) at $2.5 \mu \mathrm{M}$ and run at low speed (approx. $18 \mu \mathrm{min}^{-1}$ ) with the flow cytometer. They were detected by their signatures in a plot of side scatter versus green fluorescence. For the detection of Prochlorococcus sp., Synechococcus sp. and picoeukaryotes, we ran the sample again without staining and at high speed (ca. $44 \mu \mathrm{l}$ $\mathrm{min}^{-1}$ ). Synechococcus sp. were detected by their signature in a plot of orange versus red fluorescence. Same signatures were used for Prochlorococcus sp. and picoeukaryotes, knowing that Prochlorococcus sp. had lower red fluorescence and no orange fluorescence, and picoeukaryotes had higher red fluorescence and no orange fluorescence. Further details can be obtained from Gasol \& Morán (1999).

Nanoeukaryote abundance was determined on $20 \mathrm{ml}$ subsamples stained with DAPI and filtered through a $0.2 \mu \mathrm{m}$ filter (Nucleopore). Stained cells were directly enumerated using epifluorescence microscopy. Cell sizes of heterotrophic bacteria, Synechococcus sp., pico- and nanoeukaryotes were measured on the same filters. To quantify phytoplankton and ciliate cell numbers, $350 \mathrm{ml}$ water samples were preserved with Lugol's solution (1\% final concentration). Subsamples of $100 \mathrm{ml}$ were transferred to settling chambers, and the major groups of nano- and microphytoplankton were quantified using an inverted microscope. Cell sizes (length and width) were measured using an ocular micrometer.

Cell biovolumes were estimated from the length and width measurements, assuming the nearest geometrical shape (Edler 1979). Carbon content was then esti- 
mated from literature conversion factors as follows: nano-eukaryotes, pg $\mathrm{C}=0.433 \times\left(\mu^{3}\right)^{0.863}$ (Verity et al. 1992); phytoplankton, pg $C$ cell $^{-1}=0.109 \times\left(\mu^{3}\right)^{0.991}$ (Montagnes et al. 1994); ciliates, 0.19 pg C $\mu^{-3}$ (Putt \& Stoecker 1989).

Total POC was measured by filtering $150 \mathrm{ml}$ water samples on pre-combusted GF/F glass fiber filters. Filters were then frozen in liquid nitrogen and kept at $-80^{\circ} \mathrm{C}$ until analysis. Prior to analysis, filters were dried at $60^{\circ} \mathrm{C}$ for $24 \mathrm{~h}$ and exposed to $\mathrm{HCl}$ vapors for $48 \mathrm{~h}$ to destroy inorganic material, dried again and analyzed with a C:H:N autoanalyzer (Perkin-Elmer 240). Particulate organic carbon measurements included both detrital and live carbon. Detrital organic carbon was estimated as the difference between total particulate organic carbon (C:H:N analysis) and total live carbon (estimated from cell counts and cell measurements).

For DOC, $20 \mathrm{ml}$ water samples were filtered through pre-combusted GF/F glass fiber filters. The filtered water was stored in glass tubes at $-20^{\circ} \mathrm{C}$ until analysis. Analysis was conducted by high-temperature catalytic oxidation with an autoanalyzer (Shimadzu TOC-5000).

Depletion rates for naturally occurring particles (i.e. seston) and DOM were calculated assuming exponential growth and clearance of prey (Frost 1972, Ribes et al. 1998). Thus, the prey growth rate $k\left(\mathrm{~h}^{-1}\right)$ was computed:

$$
k=\ln \left(C_{1} / C_{0}\right) /\left(t_{1}-t_{0}\right)
$$

where $C_{0}$ and $C_{1}$ are the prey concentrations in the chamber at the initial time $t_{0}$ and at the final time $t_{1}$. The clearance rate CR (volume swept clear per biomass per time) was computed as follows:

$$
\mathrm{CR}=V(g / b)
$$

where $V$ is the volume of the chamber, $b$ is the biomass of the colony (number of polyps, dry mass [DM] or AFDM) and $g$ is the grazing coefficient $\left(\mathrm{h}^{-1}\right)$, calculated as:

$$
g=k_{\mathrm{C}}-k_{\mathrm{g}}
$$

where $k_{\mathrm{c}}$ is the prey growth rate in the control chamber, and $k_{\mathrm{g}}$ is the apparent growth in the grazing chamber. Finally, the ingestion rate $I$ (particles ingested ind. ${ }^{-1}$ time $^{-1}$ ) was calculated as:

$$
I=\mathrm{CR} \times C
$$

where $C$ is the prey concentration.

The significance of predation on each kind of prey was tested by comparing growth rates of prey in control and experimental chambers with a 2-tailed Wilcoxon test (Sokal \& Rohlf 1995).

Respiration rates. Respiration was estimated simultaneously with the feeding experiments. Oxygen con- centration and temperature were continuously measured with WTW electrodes in both chambers, and the data were recorded every $10 \mathrm{~min}$ by a data-logger. Respiration rates were estimated from the decrease in oxygen concentration in the gorgonian chamber during each experimental period. The control chamber was used to detect possible oxygen variation not due to the gorgonian colony. A respiratory quotient (RQ) of 0.75, the mean value reported for several benthic marine invertebrates (Hatcher 1989), was used. Oxygen units were converted to carbon equivalents using a carbon to oxygen conversion factor of 0.281 , calculated from the equation described by McCloskey et al. (1978).

The total number of polyps present in each of the 6 incubated colonies was counted under the stereomicroscope. The estimate of the number of polyps was facilitated by the distribution of the polyps on the branches of Leptogorgia sarmentosa, as polyps are in a single row along the 2 sides of the branches. L. sarmentosa colonies were rinsed to remove salts; DM was determined by drying at $90^{\circ} \mathrm{C}$ for $24 \mathrm{~h}$ and AFDM by combustion at $450^{\circ} \mathrm{C}$ for $5 \mathrm{~h}$.

Data of feeding on zooplankton by Leptogorgia sarmentosa comes from a previous study (Rossi 2002) and is used when examining the contribution of the different food sources to the energy demand of the species, in order to consider the entire spectrum of food sources.

\section{RESULTS}

\section{Feeding on DOC, detrital POC and live carbon $<100 \mu \mathrm{m}$}

Fig. 1 shows prey growth rates in the control chamber and in the chamber with the octocoral, for the different food sources considered as potential diet items. Differences in the growth rate between control and experimental chambers were used to measure depletion by the octocoral. The growth rate of nanoeukaryotes, diatoms, dinoflagellates and ciliates, as well as detrital POC, was significantly greater in the octocoral chamber than in the control chamber (Fig. 1). Therefore, Leptogorgia sarmentosa significantly captured nanoeukaryotes, diatoms, dinoflagellates and ciliates as well as detrital POC. No significant decrease in abundance of DOC nor in abundance of prey items smaller than nanoeukaryotes (mean \pm SE: $3.6 \pm 1.4$ ) in the presence of $L$. sarmentosa relative to the control was observed.

There were no significant differences in mean specific clearance rate $\left(\mathrm{CR}_{\mathrm{AFDM}}\right)$ for the different food sources that were captured by Leptogorgia sarmentosa 


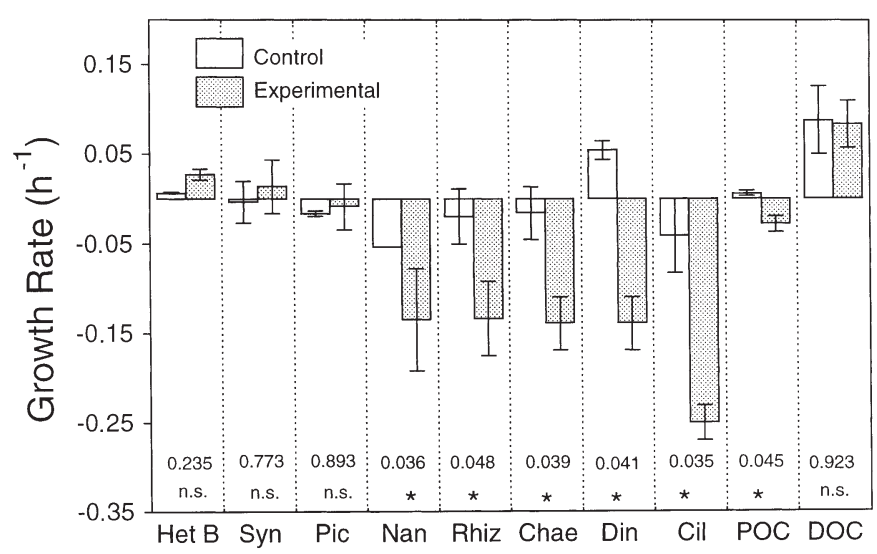

Fig. 1. Leptogorgia sarmentosa. Growth rates of prey (mean \pm $\mathrm{SE}$ ) in the octocoral chamber (dark bars) and control chamber (empty bars) for each plankton group. Maximum length $(\mu \mathrm{m})$ of each group (mean $\pm \mathrm{SE}$ ) is at the bottom of the figure. Het B: heterotrophic bacteria, Syn: Synechococcus sp., Pic: autotrophic picoeukaryotes, Nan: autotrophic nanoeukaryotes, Rhi: Rhizosolenia sp., Chae: Chaetoceros sp., Din: dinoflagellates, Cil: ciliates, POC: detrital particulate organic carbon, DOC: dissolved organic carbon. Plots represent a mean value of 6 different experiments with 6 different colonies. The degree of significance from a 2-tailed Wilcoxon test is also shown. n.s.: not significant, ${ }^{*} \mathrm{p}<0.05$

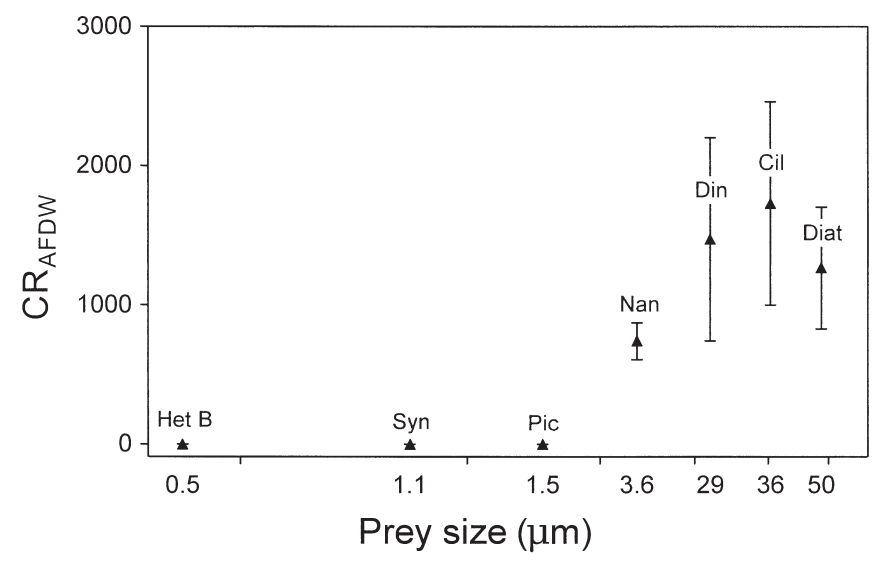

Fig. 2. Leptogorgia sarmetosa. Specific ash-free dry mass clearance rate $\left(\mathrm{CR}_{\mathrm{AFDM}} ; \mathrm{ml}\right.$ swept clear $\mathrm{g} \mathrm{AFDM}^{-1} \mathrm{~h}^{-1}$, mean \pm $\mathrm{SE})$ as a function of prey size $(\mu \mathrm{m})$. Prey size in log scale. Diat: diatoms, other abbreviations as in Fig. 1

(Fig. 2; Kruskal-Wallis test, $H=1.07, \mathrm{df}=19, \mathrm{p}=0.89$ ). Fig. 3 shows the relationship between food biomass and ingestion rates in the feeding experiments. This relationship suggests that ingestion of nanoeukaryotes, dinoflagellates, diatoms and ciliates by L. sarmentosa depended on both prey size and abundance. Ingestion of the large $(69 \mu \mathrm{m})$ but not abundant centric diatoms of the genus Rhizosolenia (the main centric diatom) was similar to that of small $(3.6 \mu \mathrm{m})$ but abundant nanoflagellates (nanoeukaryotes), indicating that

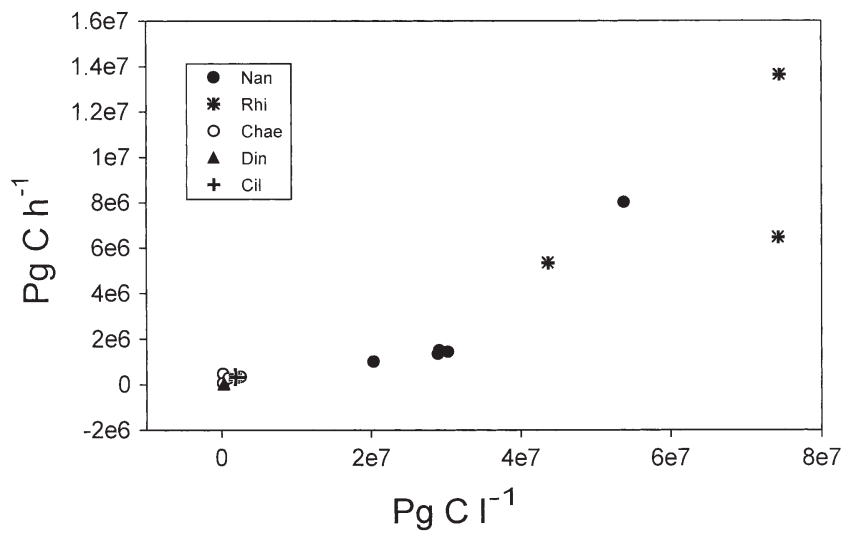

Fig. 3. Leptogorgia sarmetosa. Relationship between food biomass $\left(\mathrm{pg} \mathrm{C}^{-1}\right)$ and ingestion rate $\left(\mathrm{pg} \mathrm{C} \mathrm{h}^{-1}\right)$. Abbreviations as in Fig. 1

these food sources were captured as a function of their availability. Ingestion rate exhibited a linear function of particle concentration (Fig. $3, \mathrm{r}^{2}=0.84, \mathrm{p}<0.0001$ ) and saturation was not observed.

Ingestion rates for all these food sources are presented in Table 1. Within the live carbon category, the highest capture rate (in terms of cells) was for nanoeukaryotes (208 cells polyp $\mathrm{p}^{-1} \mathrm{~h}^{-1}$ ). However, in biomass terms, the large cells of diatoms accounted for a contribution to the ingesta similar to that of nanoeukaryotes. The ingestion rate of detrital POC was about 6 times that of live carbon $(402 \pm 35 \mathrm{vs} 67 \pm 6 \mu \mathrm{g}$ C g AFDM ${ }^{-1} h^{-1}$, mean \pm SE). Therefore, feeding on live carbon and detrital POC accounted for a total of $469 \pm 90 \mu \mathrm{g} \mathrm{C} \mathrm{g} \mathrm{AFDM}{ }^{-1} \mathrm{~h}^{-1}$ (Table 1). However, it should be noted that the specific clearance rate was always estimated for colonies with expanded polyps. Leptogorgia sarmentosa exhibits a seasonal pattern of polyp expansion (Rossi 2002). Therefore, in order to calculate the daily amount of carbon ingested from grazing on nanoeukaryotes, dinoflagellates, diatoms, ciliates and detrital POC, 3 factors were considered: (1) mean specific clearance rate estimated for the species; (2) mean concentration for each prey type in spring (data collected at the same study site and depth during an annual cycle; Ribes et al. 1999b); (3) daily mean number of hours for which the colonies have expanded polyps in spring $\left(13.0 \pm 2.5 \mathrm{~h}\right.$, mean $\pm \mathrm{SD}_{\text {; }}$ data from Rossi 2002). These 3 factors allowed us to estimate the daily ingestion rate on these food sources in spring. According to these estimates, the species ingested $5200 \pm 700 \mu \mathrm{g} \mathrm{C} \mathrm{g} \mathrm{AFDM}{ }^{-1} \mathrm{~d}^{-1}$ (mean $\pm \mathrm{SE}$ ) from feeding on detrital POC, and $870 \pm 80 \mu \mathrm{g} \mathrm{g}$ $\mathrm{AFDM}^{-1} \mathrm{~d}^{-1}$ (mean $\pm \mathrm{SE}$ ) from feeding on nanoeukaryotes, dinoflagellates, diatoms, and ciliates.

Assessment of the contribution of the different food sources to the diet of the species in spring can be con- 
Table 1. Leptogorgia sarmentosa capture rates (mean $\pm \mathrm{SE}$ ) of nanoeukaryotes, diatoms, dinoflagellates and ciliates expressed as cell number, carbon (C) per polyp, per dry mass (DM) and per ash-free dry mass (AFDM)

\begin{tabular}{|c|c|c|c|c|c|c|}
\hline Ingestion & Nanoeukaryotes & Diatoms & Dinoflagellates & Ciliates & Detrital POC & Total \\
\hline Cells polyp ${ }^{-1} \mathrm{~h}^{-1}$ & $208 \pm 65$ & $4.5 \pm 0.9$ & $0.5 \pm 0.3$ & $0.04 \pm 0.02$ & & $213 \pm 68$ \\
\hline$\mu \mathrm{g} C$ polyp $^{-1} \mathrm{~h}^{-1}$ & $\begin{array}{r}2.7 \times 10^{-3} \\
\pm 8.4 \times 10^{-4}\end{array}$ & $\begin{array}{r}4.2 \times 10^{-3} \\
\pm 9.5 \times 10^{-4}\end{array}$ & $\begin{array}{r}2.5 \times 10^{-5} \\
\pm 9.8 \times 10^{-6}\end{array}$ & $\begin{array}{r}6.0 \times 10^{-5} \\
\pm 2.2 \times 10^{-5}\end{array}$ & $\begin{array}{r}6.1 \times 10^{-2} \\
\pm 2.2 \times 10^{-3}\end{array}$ & $\begin{array}{r}6.8 \times 10^{-2} \\
\pm 3.2 \times 10^{-3}\end{array}$ \\
\hline$\mu g \mathrm{Cg} \mathrm{DM}{ }^{-1} \mathrm{~h}^{-1}$ & $6.4 \pm 1.5$ & $19 \pm 4$ & $0.1 \pm 0.07$ & $0.03 \pm 0.01$ & $127 \pm 2$ & $147 \pm 12$ \\
\hline$\mu \mathrm{g} \mathrm{Cg} \mathrm{AFDM}^{-1} \mathrm{~h}^{-1}$ & $20 \pm 7$ & $46 \pm 12$ & $0.23 \pm 0.11$ & $0.64 \pm 0.2$ & $402 \pm 35$ & $469 \pm 90$ \\
\hline
\end{tabular}

ducted by comparing ingestion of detrital POC and live carbon $<100 \mu \mathrm{m}$ to that of zooplankton $(4200 \mu \mathrm{g} \mathrm{C}$ g AFDM ${ }^{-1} \mathrm{~d}^{-1}$, Rossi 2002). Total ingesta for the species in spring was estimated as $10.3 \pm 0.7 \mathrm{mg} \mathrm{C} \mathrm{g} \mathrm{AFDM}^{-1}$ $\mathrm{d}^{-1}$. Ingestion of detrital POC, zooplankton and live carbon $<100 \mu \mathrm{m}$ in spring accounted for 51, 41 and $8 \%$ of total ingesta in carbon units, respectively.

\section{Respiration rate}

Respiration rate was estimated from the decrease in oxygen concentration in the experimental chamber (with octocoral), because oxygen concentration in the control never changed significantly over time. Initial oxygen concentrations were always saturated or supersaturaded, and the experiments always ended before oxygen concentration had dropped $10 \%$ from saturation. Respiration rate was $0.55 \pm 0.24 \mathrm{mg} \mathrm{O}_{2} \mathrm{~g} \mathrm{AFDM}^{-1}$ $\mathrm{h}^{-1}$ (mean $\pm \mathrm{SE}$ ), which is equivalent to a daily requirement of $0.022 \pm 0.010 \mu \mathrm{g} \mathrm{C}$ polyp ${ }^{-1} \mathrm{~h}^{-1}$ (mean $\pm \mathrm{SE}$ ) or $155 \pm 67 \mu \mathrm{g} \mathrm{C} \mathrm{g} \mathrm{AFDM}{ }^{-1} \mathrm{~h}^{-1}$. Temperature during the experiments ranged between 16.5 and $18^{\circ} \mathrm{C}$.

\section{DISCUSSION}

\section{Diet}

Feeding on nanoeukaryotes, dinoflagellates, diatoms, ciliates and detrital POM has received less attention than gut content examinations. In this study, we considered all sources of DOC and POC (including detrital POC and live carbon $<100 \mu \mathrm{m}$ ) as potential food sources. Live carbon included prokaryotes, picoand nanoeukaryotes, diatoms, dinoflagellates and ciliates. Leptogorgia sarmentosa captured nanoeukaryotes, diatoms, dinoflagellates, ciliates, as well as detrital POC, but no significant capture of prey items smaller than nanoeukaryotes $(3.6 \pm 1.4 \mu \mathrm{m}$, mean $\pm \mathrm{SD})$ was observed. A previous study showed that the main zooplankton prey items captured by L. sarmentosa were characterized by small size (80 to $200 \mu \mathrm{m})$ and low mobility (i.e. eggs and larvae; Rossi 2002). The capture of small-size low-motility prey and particles by L. sarmentosa agrees with previous feeding reports on octocorals (Lewis 1982, Sebens \& Koehl 1984, Coma et al. 1994, Fabricius et al. 1995, 1998, Ribes et al. 1998, 1999a, Fabricius \& Dommisse 2000). This suggests that all of these sestonic fractions appear to be ubiquitous components of the diet of octocorals. This is related to the fact that octocorals have a relatively low variety and density of nematocysts (Mariscal \& Bigger 1977) and, therefore, are passive suspension feeders that mainly capture prey items with little or no escape capacity. The importance of their quantitative contribution to the diet will be discussed (see 'Contribution of the different food sources to the diet').

\section{Prey capture rate}

The capture rate of live carbon $<100 \mu \mathrm{m}$ estimated for Leptogorgia sarmentosa $\left(91 \pm 32 \mathrm{ng} \mathrm{C}\right.$ polyp ${ }^{-1} \mathrm{~d}^{-1}$, mean $\pm \mathrm{SE}$ ) was higher than rates previously estimated for the temperate species Paramuricea clavata (6.2 ng C polyp ${ }^{-1} \mathrm{~d}^{-1}$, ranging between 0.3 and $22.8 \mathrm{ng} \mathrm{C}$ polyp $\mathrm{p}^{-1} \mathrm{~d}^{-1}$ over the annual cycle, Ribes et al. 1999a) and the tropical species Plexaura flexuosa (4.0 ng C polyp ${ }^{-1} \mathrm{~d}^{-1}$, Ribes et al. 1998).

Flow speed, particle size and density, and size and spacing of filter elements have been suggested as the main variables affecting the efficiency with which particles are captured by organisms such as octocorals (Shimeta \& Jumars 1991). Because all 3 species were examined at the same flow speed and with the same methodology, the main variables that explain differences in prey capture are prey concentration and prey capture structures. Leptogorgia sarmentosa feeding experiments were conducted in spring with relatively high prey concentration (diatoms: 46.0 cells $\mathrm{ml}^{-1}$, dinoflagellates 4.7 cells $\mathrm{ml}^{-1}$, ciliates 1.2 cells $\mathrm{ml}^{-1}$ ). Therefore, part of the difference in prey capture in comparison to Plexaura flexuosa may be attributed to the relatively low prey concentration for the tropical species (diatoms: 2.0 cells ml $^{-1}$, dinoflagellates 2.3 cells $\mathrm{ml}^{-1}$, ciliates 0.6 cells ml${ }^{-1}$; Ribes et al. 1998). However, Paramuricea clavata and L. sarmentosa were studied 
at the same site and under the same prey concentrations, with capture rate of $L$. sarmentosa (91 ng C poly $\mathrm{p}^{-1} \mathrm{~d}^{-1}$ ) ca. 4-fold higher than the highest value reported for P. clavata (22.8 $\mathrm{ng} \mathrm{C}$ polyp $\left.\mathrm{p}^{-1} \mathrm{~d}^{-1}\right)$. Prey capture in anthozoans appears to be mainly conducted by means of tentacular feeding. Direct interception and sieving are the primary modes of capture (Sebens et al. 1998). Therefore, characteristics of prey capture structures of both species may explain the higher capture rate of $L$. sarmentosa. For example, the smaller spacing between pinnules $(185 \pm 21 \mu \mathrm{m}$, mean $\pm \mathrm{SD})$ and between tentacle tips $(1775 \pm 266 \mu \mathrm{m})$ of L. sarmentosa with respect to $P$. clavata ( $255 \pm 42$ and $2175 \pm 448 \mu \mathrm{m}$, respectively; $M$. R. unpubl. data) may provide a higher efficiency for feeding on small plankton and particles.

The ingestion rate is expected to exhibit a linear function of particle concentration until it reaches a plateau, where ingestion rate saturates (Rigler 1961, Anthony 1999). Although the study was conducted in spring, the period of highest abundance of food resources (Ribes et al. 1999b), the relationship between particle concentration and ingestion rate was linear and saturation was not observed. A similar pattern had been previously observed for the gorgonian Paramuricea clavata at the same location (Ribes et al. 1999a, authors' unpubl. data). This pattern is also consistent with those observed in several coral species examined over a wide range of suspended particulate matter (Anthony 1999), where only 1 species (Porites cylindrica) conformed to the curvilinear saturationkinetics model. Anthony (1999) extensively discussed a number of hypotheses that may contribute to understanding this pattern. In our study this could be related to the relatively low natural food concentration (maximum values always $<1 \mathrm{mg} \mathrm{l}^{-1}$ of total POC and $<1 \mu \mathrm{g}$ chl a $\mathrm{l}^{-1}$ throughout the annual cycle; Ribes 1998, Ribes et al. 1999b).

\section{Respiration and ingesta}

The respiration rate of Leptogorgia sarmentosa $\left(0.55 \mathrm{mg} \mathrm{O}_{2} \mathrm{~g} \mathrm{AFDM}^{-1} \mathrm{~h}^{-1}\right.$ ) was similar to those obtained for other temperate octocorals without symbionts, which range between 0.21 and $1.00 \mathrm{mg} \mathrm{O}_{2} \mathrm{~g}$ $\mathrm{AFDM}^{-1} \mathrm{~h}^{-1}$ (Bradfield \& Chapman 1965, Mori 1968, Sebens 1987, Patterson \& Sebens 1989, Coma et al. 2002). However, it was among the lowest values observed in tropical octocorals, with symbionts which range between 0.15 and $2.30 \mathrm{mg} \mathrm{O}_{2} \mathrm{~g} \mathrm{AFDM}^{-1} \mathrm{~h}^{-1}$ (Svoboda \& Ott 1978, Lewis \& Post 1982, Fabricius \& Klumpp 1995, Ribes et al. 1998). This result reinforces the hypothesis of higher respiration rates in octocoral species with symbionts in comparison to those without. However, it is unknown to what extent this difference could be driven by the presence of symbionts or by temperature differences.

The exact nutritional requirements of Leptogorgia sarmentosa are difficult to ascertain. However, respiration accounts for an important portion of the energy demand. Therefore, the comparison between energy intake and respiratory demand (in carbon units) may explain the extent to which the different food sources examined can account for the energy demand of the species. Average detrital POC, live carbon $<100 \mu \mathrm{m}$ and zooplankton ingesta in spring was estimated to be $644 \pm 78 \mu \mathrm{g} \mathrm{C} \mathrm{g} \mathrm{AFDM}^{-1} \mathrm{~h}^{-1}$. If the ingested carbon is corrected by assimilation efficiencies from literature values $75 \%$ for live carbon and zooplankton, Zamer 1986; $30 \%$ for detrital POC, Wotton 1992), then average intake was $302 \pm 43 \mu \mathrm{g} \mathrm{C} \mathrm{g} \mathrm{AFDM}^{-1} \mathrm{~h}^{-1}$, which can account for a respiratory demand of $155 \mu \mathrm{g} \mathrm{C} \mathrm{g}$ $\mathrm{AFDM}^{-1} \mathrm{~h}^{-1}$.

\section{Contribution of the different food sources to the diet}

The contribution of the different food sources to the diet differed markedly, in that detrital POC accounted for the largest share of total ingesta. However, feeding on zooplankton also needs to be taken into account when examining the contribution of the entire spectrum of food sources to the energy demand of the species. Considering the previously estimated zooplankton ingesta throughout the annual cycle $(4200 \mu \mathrm{g} \mathrm{C}$ g $\mathrm{AFDM}^{-1} \mathrm{~d}^{-1}$ in spring; Rossi 2002), Leptogorgia sarmentosa total ingesta in spring would range between 8.7 and $11.0 \mathrm{mg} \mathrm{C} \mathrm{g} \mathrm{AFDM}{ }^{-1} \mathrm{~d}^{-1}$. Therefore, if the ingested carbon is corrected by assimilation efficiencies from the literature (see above), microzooplankton contributed the largest share to the diet $(61.0 \%)$. Detrital POC and live carbon $<100 \mu \mathrm{m}$ accounted for 30.4 and $8.6 \%$ of total assimilated carbon, respectively. This estimate modifies the previous assumptions regarding the contribution of food sources to the diet, previously conducted on the basis of ingesta (see 'Results'). However, the same pattern, with microzooplankton and detrital POC representing the bulk of the diet remains.

The contribution of food sources to the diet of Leptogorgia sarmentosa resembled those estimated for the other species where the whole spectra of potential food sources have been examined (Paramuricea clavata: zooplankton $\sim 48 \%$, detrital POC $\sim 48 \%$, live carbon $<100 \mu \mathrm{m} \sim 4 \%$, Ribes et al. 1999a). The contribution of live carbon to the respiratory demand of Plexaura flexuosa ( 0.1\%; Ribes et al. 1998) indicates that live carbon $<100 \mu \mathrm{m}$ accounts for an even lower share of the diet of this tropical species. Two general patterns in the diet of octocorals emerge from this and previous feeding studies (Leversee 1976, Lasker 1981, Lewis 
1982, Lasker et al. 1983, Sebens \& Koehl 1984, Coma et al. 1994, Fabricius et al. 1995, 1998, Ribes et al. 1998, 1999a, Fabricius \& Dommisse 2000). First, octocorals feed on a wide spectrum of food sources ranging from ca. $4 \mu \mathrm{m}$ (nanoeukaryotes) to seston particles measuring several hundred microns. Second, despite the wide spectrum of food sources present in the diet of octocorals, 2 facts suggest that detrital POC and microplankton constitute the bulk of the heterotrophic diet of octocorals. First, the 2 species where the whole spectra of potential food sources has been studied exhibited a similar pattern of contribution of the different food sources (see above). Second, this pattern is consistent with feeding studies conducted on fractions of the diet (microzooplankton: Lewis 1982, Sebens \& Koehl 1984, Coma et al. 1994; phytoplankton: Fabricius et al. 1995, 1998, Ribes et al. 1998, 1999a; detrital POC: Ribes et al. 1999a, Fabricius \& Dommisse 2000).

The present study has some weaknesses. First, the study was based on experiments conducted only in spring. Second, it is difficult to quantify the importance of detrital POM as a food source because of its wide range of nutritive value (Tenore et al. 1982). We used assimilation efficiency values from the literature that have been commonly found for benthic suspension feeders (Wotton 1992) and that we have used in previous studies so as not to affect the comparison with other species with an unmeasured factor (Ribes et al. 1999a). Nevertheless, although detrital POC is a poorquality food source, it constitutes the most abundant source of nutrition in the water column all year around at the study site (Ribes et al. 1999b, Coma \& Ribes 2003), as in many other temperate areas (e.g. Mann 1982). Furthermore, due to the dependence of particle capture on flow speed (e.g. Dai \& Lin 1993, Fabricius et al. 1995), the estimated capture rates may be an underestimation because estimates of detrital POC and live carbon ingesta were conducted at low flow speed.

Abundance of detrital POC exhibits a marked variation throughout the annual cycle, with minimum values during summer, in contrast to that of live carbon $<100 \mu \mathrm{m}$ and zooplankton (Ribes et al. 1999b, Coma \& Ribes 2003). Flow speed also has a marked seasonal pattern, being higher during winter and spring and decreasing in summer (Font et al. 1995). Also, the contribution of detrital POC to the diet of octocorals suggests that there may be important seasonal variations in energy intake, especially during summer, due to the marked seasonal variation in detrital POC abundance and flow speed at the study site (Font et al. 1995, Ribes et al. 1999b). A marked seasonal variation in energy intake may strongly affect the seasonal pattern of investment in secondary production (i.e. growth and reproduction) and the behavior of temperate octocorals. This would be consistent with the predominant pattern of summer dormancy and low or no investment in secondary production during summer observed in the Mediterranean during summer in most taxa that feed mainly on detrital POC and microplankton (Coma et al. 2000, Coma \& Ribes 2003). The capture of DOC, pico- and nanoplankton, and particles $<3 \mu \mathrm{m}$ does not significantly contribute to the diet of these taxa, which include anthozoans, bivalves and most hydrozoan species studied to date in the Mediterranean (Coma et al. 2000, Coma \& Ribes 2003). Further research on the variation of the ingesta and respiration of the species throughout the annual cycle, as well as on the annual pattern of investment in growth and reproduction, needs to be conducted to address this issue.

Acknowledgements. We are grateful to E. F. Cox and J. M. Gili for critical reading and valuable comments on the manuscript. The flow cytometry measurements were carried out at the ICM-CSIC (Barcelona-Spain) with the assistance of Pep Gasol. POC and DOC analyses were provided by the Scientist Technical Service (University of Barcelona) with the assistance of I. Casals and P. Fernandez. Support for this work was provided by a 'Ramón y Cajal' research contract from the 'Ministerio de Ciencia y Tecnología' (MCT) to M.R., by a research contract from MCT to R.C., and by a MCT fellowship to S.R. This paper was funded in part by DGICYT grants REN2000-0633-C03-01/MAR and REN2002-01631/MAR.

\section{LITERATURE CITED}

Anthony KRN (1999) Coral suspension feeding on fine particulate matter. J Exp Mar Biol Ecol 232:85-106

Bradfield AE, Chapman G (1965) The oxygen consumption of Pennatula rubra Ellis and some other anthozoans. Z Vergl Physiol 50:363-370

Carpine C (1963) Contribution à la conaissance des Gorgones Holaxonia de la Méditerranée occidentale. Bull Inst Océanogr Monaco 1270:1-52

Cloern JE (1982) Does the benthos control phytoplankton biomass in south San Francisco Bay? Mar Ecol Prog Ser 9: 191-202

Coma R, Ribes M (2003) Seasonal energetic constraints in Mediterranean benthic suspension feeders: effects at different levels of ecological organization. Oikos 101:205-215

Coma R, Gili JM, Zabala M, Riera T (1994) Feeding and prey capture cycles in the aposymbiontic gorgonian Paramuricea clavata. Mar Ecol Prog Ser 115:257-270

Coma R, Ribes M, Gili JM, Zabala M (1998) An energetic approach to the study of life-history traits of two modular colonial benthic invertebrates. Mar Ecol Prog Ser 162:89-103

Coma R, Ribes M, Gili JM, Zabala M (2000) Seasonality in coastal benthic ecosystems. Trends Ecol Evol 15:448-453

Coma R, Ribes M, Gili JM, Zabala M (2002) Seasonality of in situ respiration rate inthree temperate benthic suspension feeders. Limnol Oceanogr 47:324-331

Crisp DJ (1984) Energy flow measurements. In: Holmes NA, McIntyre AD (eds) Methods for the study of marine benthos. IBP Handbook 16. Blackwell Scientific Publications, Oxford, p 284-372

Dai CF, Lin MC (1993) The effects of flow on feeding of three gorgonians from southern Taiwan. J Exp Mar Biol Ecol 173:57-69 
Dayton PK, Oliver JS (1977) Antarctic soft-bottom benthos in oligotrophic and eutrophic environments. Science 197: 55-58

Edler L (1979) Recommendations for marine biological studies in the Baltic sea: phytoplankton and chlorophyll. Baltic Mar Biol 5:5-38

Fabricius KE, Dommisse M (2000) Depletion of suspended particulate matter over coastal reef communities dominated by zooxanthellate soft corals. Mar Ecol Prog Ser 196: $157-167$

Fabricius KE, Klumpp DW (1995) Widespread mixotrophy in reef-inhabiting soft corals: the influence of depth, and colony expansion and contraction on photosynthesis. Mar Ecol Prog Ser 125:195-204

Fabricius KE, Genin A, Benayahu Y (1995) Flow-dependent herbivory and growth in zooxanthellae-free soft corals. Limnol Oceanogr 40:1290-1301 (Erratum Limnol Oceanogr 41:1520)

Fabricius KE, Yahel G, Genin A (1998) In situ depletion of phytoplankton by an azooxanthellate soft coral. Limnol Oceanogr 43:354-356

Font J, Garcia E, Gorriz E (1995) The seasonality of mesoscale motion in the Northern Current of the western Mediterranean: several years of evidence. Oceanol Acta 18:207-219

Fréchette M, Butman CA, Geyer WR(1989) The importance of boundary-layer flow in supplying phytoplankton to the benthic suspension feeder, Mytilus edulis L. Limnol Oceanogr 34:19-36

Frost BW (1972) Effects of size and concentration of food particles on the feeding behavior of the marine planktonic copepod Calanus pacificus. Limnol Oceanogr 17:805-815

Gasol JM, Morán XAG (1999) Effects of filtration on bacterial activity and picoplankton community structure as assessed by flow cytometry. Aquat Microb Ecol 16:251-264

Gili JM, Coma R (1998) Benthic suspension feeders: their paramount role in littoral marine food webs. Trends Ecol Evol 13:316-321

Graff G (1992) Benthic-pelagic coupling: a benthic review. Oceanogr Mar Biol 30:149-190

Hatcher A (1989) RQ of benthic marine invertebrates. Mar Biol 102:445-452

Kinzie RA III (1973) The zonation of West Indian gorgonians. Bull Mar Sci 23:93-155

Lasker HR (1981) A comparison of the particulate feeding abilities of three species of gorgonian soft coral. Mar Ecol Prog Ser 5:61-67

Lasker HR, Gottfried MD, Coffroth MA (1983) Effects of depth on the feeding capabilities of two octocorals. Mar Biol 73: $73-78$

Leversee GJ (1976) Flow and feeding in fan-shaped colonies of the gorgonian coral, Leptogorgia. Biol Bull 151:344-356

Lewis JB (1982) Feeding behaviour and feeding ecology of the Octocorallia (Coelenterata: Anthozoa). J Zool Lond 196:371-384

Lewis JB, Post EE (1982) Respiration and energetics in West Indian Gorgonacea. Anthozoa, Octocorallia. Comp Biochem Physiol A 71:457-459

Mann KH (1982) Ecology of coastal waters: a system approach. Blackwell Scientific Publications, London

Mariscal RN, Bigger CH (1977) Possible ecological significance of octocoral epithelial ultrastructure. Proc 3rd Int Coral Reef Symp 1:127-134

McCloskey LR, Wethey DS, Porter JW (1978) Measurements and interpretation of photosynthesis and respiration in reef corals. In: Stoddart DR, Johannes RE (eds) Coral reefs: research methods. Monogr Oceanogr Methodol (UNESCO) 5:379-396
Mistri M (1995) Population structure and secondary production of the Mediterranean Octocoral Leptogorgia sarmentosa (L.1758). PSZN I: Mar Ecol 16:181-188

Mistri M, Ceccherelli VU (1993) Growth of the Mediterranean gorgonian Lophogorgia ceretophyta (L.1758). PSZN I: Mar Ecol 14:329-340

Montagnes DJ, Berges SJA, Harrison PJ, Taylor FJR (1994) Estimating carbon, nitrogen, protein and chlorophyll a from volume in marine phytoplankton. Limnol Oceanogr 39:1044-1060

Mori S (1968) Influence of environmental and physiological factors on the daily rhythmic activity of a sea pen. Cold Spring Harbor Symp Quant Biol 25:333-344

Officer CB, Smayda TJ, Mann R (1982) Benthic filter feeding: a natural eutrophication control. Mar Ecol Prog Ser 9:203-210

Olson RR, Olson MH (1989) Food limitation of planktotrophic marine invertebrate larvae: does it control recruitment success? Annu Rev Ecol Syst 20:225-248

Patterson MR, Sebens KP (1989) Forced convection modulates gas exchange in cnidarians. Proc Natl Acad Sci USA 86: 8833-8836

Petersen JK, Riisgård HU (1992) Filtration capacity of the ascidian Ciona intestinalis and its grazing impact in shallow fjord. Mar Ecol Prog Ser 88:9-17

Peterson CH, Black R (1987) Resource depletion by active suspension feeders on tidal flats: influence of local density and tidal elevation. Limnol Oceanogr 32:143-166

Putt M, Stoecker DK (1989) An experimentally determined carbon volume ratio for marine 'oligotrichous' ciliates from estuarine and coastal waters. Limnol Oceanogr 34: 1097-1103

Ribes M (1998) Feeding activity and diet of benthic suspension feeders related to metabolic requirements and seston composition. PhD thesis, University of Barcelona

Ribes M, Coma R, Gili JM (1998) Heterotrophic feeding by gorgonian corals with symbiotic zooxanthellae. Limnol Oceanogr 43:1170-1179

Ribes M, Coma R, Gili JM (1999a) Heterogeneous feeding in benthic suspension feeders: the natural diet and grazing rate of the temperate gorgonian Paramuricea clavata (Cnidaria: Octocorallia) over a year cycle. Mar Ecol Prog Ser 183:125-137

Ribes M, Coma R, Gili JM (1999b) Seasonal variations of particulate organic carbon, dissolved organic carbon and the contribution of the microbial communities to the live particulate organic carbon in a shallow near-bottom ecosystem at the northwestern Mediterranean Sea. J Plankton Res 21:1077-1100

Ribes M, Coma R, Gili JM, Svoboda A, Julià A, Parera J (2000) A 'semi-closed' recirculating system for the in situ study of feeding and respiration of benthic suspension feeders. Sci Mar 64:265-275

Rigler FH (1961) The relationship between concentration of food and feeding rate of Daphnia magna Straus. Can J Zool 39:857-868

Riisgård HU, Poulsen L, Larsen PS (1996) Phytoplankton reduction in near-bottom water caused by filter-feeding Nereis diversicolor-implications for worm growth and population grazing impact. Mar Ecol Prog Ser 141:47-54

Rossi S (2002) Environmental factors affecting the trophic ecology of benthic suspension feeders. PhD thesis, University of Barcelona

Schoener TW (1974) resource partitioning in ecological communities. Science 185:27-39

Sebens KP (1987) Coelenterata. In: Pandian TJ, Vernberg FJ (eds) Animal energetics, Vol 1. Academic Press, San Diego, p 55-120 
Sebens KP, Koehl MAR (1984) Predation on zooplankton by the benthic anthozoans Alcyonium sidereum (Alcyonacea) and Metridium senile (Actiniaria) in the New England subtidal. Mar Biol 81:255-271

Sebens KP, Grace SP, Helmut B, Maney EJ, Miles JS (1998) Water flow and prey capture by three scleractinian corals, Madracis mirabilis, Monastrea cavernosa and Porites porites, in a field enclosure. Mar Biol 131:347-360

Shimeta J, Jumars PA (1991) Physical mechanisms and rates of particle capture by suspension feeders. Oceanogr Mar Biol 29:191-257

Sokal R, Rohlf FJ (1995) Biometry. The principles and practice of statistics in biological research, 3rd edn. WH Freeman \& Co, New York

Starmans A, Gutt J, Arntz WE (1999) Mega-epibenthic communities in Artic and Antartic shelf areas. Mar Biol 135: 269-280

Svoboda A, Ott J (1978) In situ monitoring of oxygen production in cnidaria with and without zooxanthellae. In: McLusky DS, Berry AJ (eds) Physiology and behaviour of marine organisms. Pergamon Press, Oxford, p 75-82

Tenore KR, Carmmen L, Findlay SEG, Phillips N (1982) Per-

Editorial responsibility: Roger Hughes (Contributing Editor), Bangor, Wales, UK spectives of research on detritus: do factors controlling the availability of detritus to macroconsumers depend on its source? J Mar Res 40:473-490

True MA (1970) Étude quantitative de quattre peuplements sciaphiles sur substrat rocheux dans la région Marseilles. Bull Inst Océanogr Monaco 1410:1-48

Verity PG, Robertson CY, Tronzo CR, Andrews MG, Nelson JR, Sieracki ME (1992) Relationships between cell volume and the carbon and nitrogen content of marine photosynthetic nanoplankton. Limnol Oceanogr 37:1434-1446

Weinberg S (1976) Revision of the common Octacorallia of the Mediterranean circalittoral. I. Gorgonacea. Beaufortia 24: 63-104

Weinberg S (1979) Autoecology of shallow-water Octocorallia from Mediterranean rocky substrata. I. The Banyuls area. Bijdr Dierkd 50:73-86

Wotton RS (1992) Particulate and dissolved organic material as food. In: Wotton RS (ed) The biology of particles in aquatic systems. CRC Press, Boca Raton, FL, p 213-261

Zamer WE (1986) Physiological energetics of the intertidal sea anemone Anthopleura elegantissima, I. Prey capture, absorption efficiency and growth. Mar Biol 92:299-314

Submitted: October 8, 2002; Accepted: February 4, 2003 Proofs received from author(s): May 8, 2003 